\title{
First report of Erysiphe arcuata on Carpinus betulus in Romania
}

\author{
Vasilică-Claudiu Chinan ${ }^{1}$ (D) Ciprian Claudiu Mânzu ${ }^{1}$
}

Received: 24 September 2020 / Accepted: 29 December 2020 / Published online: 13 January 2021

(C) Società Italiana di Patologia Vegetale (S.I.Pa.V.) 2021

Keywords Erysiphe arcuata $\cdot$ Powdery mildew $\cdot$ Carpinus betulus $\cdot$ Romania

In Romania, Carpinus betulus L. is widely distributed in temperate deciduous forests, but is also cultivated in urban green spaces. During the field activities conducted in October 2017 in Romania, trees of $C$. betulus affected by powdery mildew were found in Iaşi city: several trees in a park (disease incidence $100 \%$ ) and several dozen in a hedgerow in the Botanical Garden (disease incidence 75\%). The symptoms displayed by the examined trees were visible on the upper surface of the leaves and the microscopic examination of the collected samples showed it to be a species of Erysiphe section Uncinula. Conidiophores were erect, cylindrical, measured $70-130 \times 7-12 \mu \mathrm{m}$, with foot cells straight accompanied by $1-3$ cells, forming conidia singly. Conidia were hyaline, ellipsoid, cylindrical or doliiform, and 30-45 × 12-14 $\mu \mathrm{m}$. Chasmothecia were amphigenous, scattered to gregarious, subglobose, dark brown, $85-130 \mu \mathrm{m}$ in diameter, showing 9-17 appendages arranged equatorially, hyaline, flexuous, circinate at apex, measuring 150-275 $\times 5-6 \mu \mathrm{m}$, with one septum near the base. The number of asci varied between 4 and 6 per chasmothecium, which were sessile to short stalked, elliptical-ovoid, measuring 40-50 $\times 30-38 \mu \mathrm{m}$, and 2-6-spored. Ascospores were hyaline, elliptical-ovoid, and 16-22 × 10$15 \mu \mathrm{m}$. These morphological characteristics matched those of Erysiphe arcuata U. Braun, V.P. Heluta \& S. Takam. (Braun et al. 2006). In order to confirm the morphological identification, the internal transcribed spacer (ITS) region of two specimens (voucher specimens I 185662 and I 185663) were amplified with the primers ITS1F and ITS4 and sequenced. The sequences were deposited in GenBank (accession Nos. MT889657 and

Vasilică-Claudiu Chinan

vasilechinan@yahoo.com

1 Faculty of Biology, "Alexandru Ioan Cuza" University of Iaşi, 20A Carol I Blvd, 700505 Iași, Romania
MT889658). A GenBank BLAST search showed 100\% similarities with those of E. arcuata AB252473 (Braun et al. 2006) and AB362817 (Pastirčáková et al. 2008). To our knowledge, this is the first report of E. arcuata in Romania (Farr and Rossman 2020).

Acknowledgements The authors would like to thank Dr. Lucian Fusu for his help with the molecular analysis.

Data availability The samples (voucher specimens I 185662 and I 185663) are deposited in the Herbarium of Alexandru Ioan Cuza University of Iaşi, Romania (Index Herbariorum abbreviation: I). The sequences obtained in this study were deposited in GenBank (accession numbers MT889657 and MT889658).

\section{Compliance with ethical standards}

Conflicts of interest/Competing interests The authors have no relevant financial or non-financial interests to disclose.

Consent to participate Not applicable.

Consent for publication Not applicable.

Code availability Not applicable.

\section{References}

Braun U, Takamatsu S, Heluta V, Limkaisang S, Divarangkoon R, Cook R, Boyle H (2006) Phylogeny and taxonomy of powdery mildew fungi of Erysiphe sect. Uncinula on Carpinus species. Mycol Prog 5:139-153. https://doi.org/10.1007/s11557-006-0509-6

Farr DF, Rossman AY (2020) Fungal Databases, U.S. National Fungus Collections, ARS, USDA. https://nt.ars-grin.gov/fungaldatabases. Accessed 24 Nov 2020

Pastirčáková K, Takamatsu S, Shiroya Y, Pastirčák M (2008) European hornbeam powdery mildew Erysiphe arcuata in Slovakia. J Phytopathol 156:597-601. https://doi.org/10.1111/j.1439-0434. 2008.01408.x

Publisher's note Springer Nature remains neutral with regard to jurisdictional claims in published maps and institutional affiliations. 